\title{
Indonesia's political culture in the new digital age: A preliminary discussion
}

\section{Budaya politik Indonesia di era digital baru: Suatu diskusi pendahuluan}

\author{
Ari Ganjar Herdiansah $^{1} \&$ Widya Setiabudi Sumadinata ${ }^{2}$
}

'Department of Political Science, Faculty of Social and Political Science, Universitas Padjajaran ${ }^{2}$ Department of International Relation, Faculty of Social and Political Science, Universitas Padjajaran Address: Jalan Raya Bandung Sumedang KM 21,Sumedang, West Java 45363

E-mail: ari.ganjar@unpad.ac.id

\begin{abstract}
The development of increasingly accessible digital media has resulted in reasonably intense dynamics of political behaviour and articulation. However, the influence of the internet and social media use on Indonesian political culture has not been much discussed. This article explains changes in contemporary Indonesia's political culture that align with the proliferation of new digital media by considering socio-political conditions and modernisation. In its analysis, this article employs a historical-comparative method with an interpretive approach. The results of this study demonstrate that the traditional conception of power relation has historically influenced Indonesian political culture. In the post-Suharto era, the direct electoral system and primacy of television media promoted popular voter preferences that degraded traditional charismatic figures. The rise of the Internet and social media then had democratising implications by increasing online public discussion. However, subsequent development of new digital media also illustrated counterproductive trajectory to democratic values as online frictions triggered ethnic and religious-based regrouping. Finally, this article considers that although widespread usage of the Internet and social media inspire democratic implications to Indonesian political culture, longstanding and deep-rooted traits, such as primordialism, persist within this more digitalised society.
\end{abstract}

Keywords: political culture; Indonesia; social media; democracy

\begin{abstract}
Abstrak
Perkembangan media digital yang semakin mudah diakses telah menghasilkan dinamika perilaku dan artikulasi politik yang cukup intens, namun pengaruh penggunaan internet dan media sosial pada budaya politik Indonesia belum banyak dibahas. Artikel ini menjelaskan perubahan-perubahan dalam budaya politik Indonesia yang sejalan dengan maraknya penggunaan media digital baru dengan mempertimbangkan kondisikondisi sosial politik dan modernisasi. Dalam analisisnya, artikel ini menggunakan metode perbandingan sejarah dengan pendekatan interpretivisme. Hasil kajian ini menunjukkan bahwa budaya politik Indonesia telah lama dibentuk oleh konsepsi relasi kekuasaan tradisional. Di era pasca-Suharto, sistem pemilihan umum secara langsung dan keutamaan media televisi telah mempromosikan preferensi pemilih popular yang mendegradasi tokoh-tokoh karismatik tradisional. Kebangkitan internet dan media sosial kemudian memberikan implikasi demokratisasi dengan meningkatkan diskusi publik secara online. Namun, perkembangan media digital juga menggambarkan lintasan kontraproduktif terhadap nilai-nilai demokratis, ketika friksi-friksi online menyulut pengelompokan berbasis etnik dan keagamaan. Akhirnya, artikel ini melihat bahwa meskipun penggunaan internet dan media sosial memberikan dampak demokratisasi terhadap budaya politik Indonesia, ciri-ciri budaya politik tradisional seperti primordialisme masih bertahan dalam masyarakat yang semakin digital.
\end{abstract}

Kata kunci: budaya politik; Indonesia; media sosial; demokrasi

\section{Introduction}

Information and Communication Technologies (ICTs) are believed to have impacted society's views toward political systems (Loader \& Mercea 2012). The growing prevalence of the Internet and social media has marked a new digital era in political processes and become a serious topic of discussion in the social studies, especially in sociology, political science, anthropology, and psychology. Many of these fields focus on the character of a new digital media platform that encourages mass collaboration among both individuals and groups and acts as emerging sources of innovation and democratic 
ideas (Leadbeater 2010). The latest forms of digital media are thought to have influenced electoral competition; candidates and political parties have and continue to race to shape public opinion through mastery of the Internet and social media.

In Indonesia, the development of media has undoubtedly impacted socio-political change. Sen \& Hill (2007), for example, reported that in the late 1990s, the development of media technology amidst substantial growth in Indonesia penetrated cultural boundaries and later challenged the dominance of the New Order regime. In the post-New Order regime, the development of increasingly accessible digital media has resulted in reasonably intense dynamics of how the competition of identity and political articulation built by the middle class (Heryanto 2008). However, the influence of the internet and social media use on Indonesian political culture has not been much discussed. The discussion of the political culture in the new digital era is critical to understanding the socio-cultural responses to political phenomena that perpetuate societies' political actions. This article gives a preliminary discussion about changes in contemporary Indonesian political culture in light of developments in new digital media. This paper focuses on the impacts of ICTs on Indonesian political culture by considering other essential elements such as socio-political conditions and modernisation. This analysis emphasises the momentum of events leading up to and following the 2014 election when political contests at the national level include online discourses and movements carried out by ordinary citizens to influence the electoral outcome (Kwok 2018).

Culture is an essential variable in any political analysis. Social scientists have long constructed conceptual frameworks in which cultures determine political outcomes. Culture is a collection of attitudes, knowledge, and values shared and transmitted across generations (Inglehart 1990). Anderson (1990) treats culture as a set of representational and behavioural characteristics that make a population different from others. As a term, political culture refers to the ideas, values, and beliefs of those who directly impact the political system (Wiarda 2014). Thus, political culture must be recognised through patterns in social situations, power relations, and authority generated by prevailing societal values and norms. The culture itself is not static or monolithic but produces a particular social and cultural ambience in a process established by existing power relations and dominating structures. Political culture, then, is an unfolding of cultural production and contestation in the political sphere (Eklof 2004).

There are two tendencies in discussions of political culture. The first stems from the perspective of behavioural studies that focus on political culture relativity in countries to explain differences in institutional implementation. Second, the sociological view that emphasises the process of modernisation which affecting the political culture formation (Welch 1993). This paper uses the sociological view that scrutinises the socio-political changes through the shifts in social and cultural values. More specifically, the explanation directed at political culture changes in the digital age, where information technology and communication media become a means for the shifting of attitudes, behaviours, and values associated with political patterns. This elaboration is essential to get a deeper understanding of the interplay between the development of digital media and political culture that shows its significance in the discourse of social, political sciences in the last two decades.

The explanation of political culture is inseparable from the typology of social characteristics that emphasise aspects of modernisation, in which education, application of technology, and forms of the social organisation play a key role. Gabriel Almond and Sidney Verba (Dalton \& Welzel 2014) were the first to attempt to construct a cultural explanation of political behaviour in their book The Civic Culture. According to them, the democratic political system cannot work in societies that less possess civic values; the society that difficult to establish norms that recognise and obey the state but also are aware of its obligation to participate in public affairs. Huntington (1991) also believed democracy aligns only within the context of western cultural values and argued that when applied to non-Western societies, democracy could not work as designed. In Asian societies, democratic political culture remains less developed because of religious barriers such as Confucianism and Islam. Nevertheless, cultural values can be changed along with the modernisation. Welch (1993) argued that the key to 
civic values lies in modernisation and, specifically, educational institutions. It means, with a decent knowledge, citizens from any cultural background can wield insight into political issues and engage in the political process.

Communication media technologies are another crucial instrument in mediating social and cultural change. It does not mean media necessarily transform societies, as the media itself is a cultural product, and media use and meaning embedded within a society's cultural conceptions. Longlasting cultural elements, such as religious traditions and national histories, shape the structure of communication systems, which in turn impact political development. From this perspective, one could argue that specific cultural values trigger political and technological change via a technological system that bridges culture and politics. Therefore, when constructing a socio-political model, it is imperative to understand the nature of this interaction between technology and culture (Skoric, Park, \& Jiang 2014).

In the new digital era, democratisation occurs within the realm of civil society, where the citizens are as free as ever to interact and foster public political discussion. Citizens can be active in following issues that interest them. They can also more effectively oversee the running of government because every bureaucratic institution is required to apply the transparency principle. The spread of smart phone usage has transformed communication from the mass to individuals that can penetrate government censorship. Digital media-based social networks allow users to acquaint themselves with the conditions that affect them and can inspire offline social movements and collective action (Stacey 2015). The widespread use of social media tools accessible via mobile phones, such as Facebook, Twitter, and YouTube, has led to breakthroughs in information dissemination and the organisation of civil society in achieving political goals. Social media's impact on democratisation is increasingly apparent. Most users of ICTs for political purposes are not activists, but ordinary people. In the new digital age, the boundaries between readers, reporters, news and opinions, information and actions have become increasingly ambiguous. Digital media has become an essential tool in political debates and political competitions by decentralising information and knowledge (Diamond 2012).

The Internet and social media's influence on democratisation cannot be isolated from the social structure, rules, and communication systems citizens employ. The impact of the Internet and social media on inclusivity in political discourse is visible in societies with pre-existing, solid democratic or semi-democratic values. Through the Internet and social media, users can freely access globally available information. Conventional media, such as newspapers, television, and radio, are monologue technologies that provide unidirectional information from a single party, and they can only build a half-democratic communication culture. However, the presence of new digital media is changing this situation. Citizens are no longer dependent on one-way information provided by conventional media. Through the Internet and social media, citizens can make decisions based on their choices, needs, and tastes. There is hope that citizens can boost their participation and better achieve their own goals. Citizens are no longer merely an object of the political process but have instead begun to shift to the role of the subject (Sparks 2014).

The emergence of new digital media has encouraged users to interact better, more evenly distribute and exchange information (demassified), and more efficiently receive and send both asynchronous and synchronously messages (Patel 2012). Through these benefits, the proliferation of the Internet and social media have also furthered functionalities for the people, i.e., for cognitive satisfaction (learning new things) and affective compliance (escaping from hectic situations), as well as fulfilling practical business, communication, and education needs. Moreover, internet and social media communication enable one to build hyper-personal characteristics, wherein users edit and organise content that selects and maximizes self-representation (Lin 2007). It will lead the Internet and social media to increase individual awareness of positions and roles in politic discourse and trigger participation. As a consequence, the Internet can mobilise users to create or share knowledge resources (Schwartz, Libicki, Taylor, Martini, \& Baxter 2013).

Despite the supportive functions, the Internet and social media have also demonstrated an unexpected impact on political processes. Opinions that develop through social media can quickly grow wild 
and destructive. Social media debates tend to inspire polarisation among communities and foster deep social cleavages. People are inclined to filter out content based on their preferences. Citizens of the Internet, or netizens, group themselves by similarities in taste and preferences for specific social, political, and religious views that can prove contrary to democratic values (Sustein 2018).

\section{Research Method}

This article employs the historical-comparative method in its analysis. This method has long been used to explain various social phenomena and social change because it enables the researcher to analyse and offer a deep insight into social issues. The issues highlighted in this method have relevance in some periods of history. Although it covers a macro-social phenomenon, historical-comparative methods remain useful in establishing a thorough comprehension of a topic. With an extensive scope, this method can encompass various complementary techniques or methods. This method provides a general explanation (Lange 2013), and, in this paper, is based on an intergenerational approach within the same societal scope that aims to identify similarities and differences between macro-social units. This method is convenient for providing understanding, explanation, and interpretation of the results and processes of different historical periods ad their significance to existing institutions (Ragin 2014). Theoretically, this article uses the concept of political culture within the interpretive approach, which emphasises the meaning of social issues contained in an event (Welch 2013).

At a practical level, this article built on a literature study that complemented by news analysis. Literature study conducted to examine the subjects and thoughts on Indonesian political culture, as carried in Clifford Geertz's (1976), Eklof (2004), Anderson (1990), and others. In explaining political culture in the Indonesian historical context, we began with scrutinising the mode of power and culture in the era of struggle for Indonesian independence and the Suharto period. On the other side, news analysis has emphasised the phenomenon of the use of the Internet and social media in political contests. The analysis was focused on the political culture dynamics related to the development of the media after the reform era, especially in the first Joko Widodo's administration (2014-2019).

\section{Results and Discussion}

\section{The characteristics of power in Indonesia's political culture}

In understanding the characteristics of the political culture in Indonesia, we seek the essential values underlying the relation of power and compliance. The efforts can be made by conducting historical traces of political vision of the founding fathers that vehemently rejected the individualism and economic liberalisation embodied in Western democracy. According to Reeve (2013), the ideas of four significant figures are widely adopted in Indonesian political and state buildings: Ki Hajar Dewantoro, Sukarno, Supomo, and Mohammad Hatta. Dewantoro uses the term kawula (commoners) and gusti (noblemen) to describe the harmonious relationship between the people and its leader. The people support leaders, and in turn, the leaders protect the people. Sukarno affirmed this concept and applied it to the term Demokrasi Terpimpin (guided democracy) between 1959-1966. Supomo honoured the traditional legal system and indigenous cultural superiority, which is a mixture of Buddhist, Hindu, Islamic and Western cultures. Meanwhile, Hatta that inspired by the ideas of Islam, socialism, and traditionalism views of collectively underlies his contribution to the construction of the nation's economy based on cooperatives and kekeluargaan (family relations principle). He also stressed the need to maintain national political values such as deliberative democracy, the people's right to protest, and helping each other.

The centralistic power not only prevails in large administrative arenas but also at the micro-level. Nordholt (2015) analyses how this centralistic pattern has caused power to converge around charismatic figures, in which ties are built vertically between the master and followers. This pattern of power has existed since the pre-colonial era. The masters provide protection and patronage in exchange for the loyalty and work of his followers. The characteristics of agrarian societies contributed to the creation of these patron-client patterns - landlords with large fields required human labour to 
produce products. The poor tenants relied on their livelihoods by debt to landlords, and it made them in a weak position. Colonial rulers later institutionalised these patron-client relationships to improve the cost efficiency of resource extraction. They used Java elites to exploit both natural and human resources. This pattern of power continued into the post-colonial era, whereas the newly established government considered the cause of rampant corruption in the 1950s. In the New Order era, patronclient relationships institutionalised through bureaucratisation.

The nature of power that demands loyalty based on primordial ties strengthen the social identity that determines political outlook. Geertz (1976) documented socio-political categorisation in Java within three major groups, priayi (Javanese aristocracy), santri (Islamic student or pious Muslim), and abangan (nominal Javanese). These characteristic variations contribute to the growth of differentiated political parties that align with traditional forms of organisation. The Partai Nasional Indonesia (PNI), for example, was dominated by Javanese abangan and priayi, who live in urban areas. The Partai Komunis Indonesia (PKI) gained support from farmers and landless labourers from Java. Supporters of Nahdlatul Ulama (NU) consisted of traditional santri who live in rural Java. Meanwhile, Masyumi's followers were sourced from modernist Muslim entrepreneurs and geographically spread wider than other parties, especially in Java. During the first election in 1955, ethnic and religious attachments were considered virtues, and primordial ties were relevant to parties' political affiliations. Four parties won the most votes, making them the most prominent and influential. They included the PNI, with 22 per cent of the vote, Masyumi with 20.9 per cent, NU with 18.4 per cent, and PKI with 16.4 per cent. These divisions between political parties indicate a broader and more pervasive social divide (Eklof 2004).

In the Suharto era, the concept of Javanese power permeated the country's political and bureaucratic realm. The Javanese conception of power differs from the Western definition of the word. Power, in Javanese culture, consists of elements historically formed from the influences of India and various Asian and non-Asian cultures. This power's characteristics include concreteness - power must be illustrated by significant artefacts that can be seen and acknowledged by others. Second, the power source must be homogeneous. The supreme ruler is of a single form, and the intermediaries below that leader absorb obedience to the supreme ruler. Third, the rhythm of power must remain constant - a ruler can never be repudiated or overthrown. Fourth, power does not require legitimacy. The people are required to submit and obey without questioning the legitimacy of the ruler to exercise his authority (Anderson 2006). The employment of traditional Javanese power is also evident in Suharto's persistent maintenance of control and elimination of opportunities for successors (Suryadinata 1997). This conception of power not only demanded regional compliance but also maintained Suharto as the central patron of the power structure, which Golkar was set as a political machine to propagate the centralisation of power (Carnegie 2008).

According to Anderson (2006), traditional Javanese conception of power is also manifest in party consolidations by the New Order regime. In 1973, the Suharto government fused political forces outside Partai Golongan Karya (Golkar) into two significant groups to create stability and encourage smooth economic development. The first group came from a spiritual rank consisting of seven Islamic parties. They joined a political party called the Partai Persatuan Pembangunan (PPP). The second group consisted of nationalists and non-Muslims, including the PNI, Partai Musyawarah Rakyat (Murba), Partai Ikatan Pendukung Kemerdekaan Indonesia (IPKI), Partai Katolik, and Partai Kristen Indonesia (Parkindo). Together, they merged into the Partai Demokrasi Indonesia (PDI) (King 2003). Primordial-based politics modified until all political forces aligned with the regime's interests (Crouch 2007). Although the party fusion aims to extract all the identity-based power under the umbrella of Golkar, the actuality of social and political identity is never extinct. The Islamic powers, both traditionalists represented by NU and the modernists by the Masyumi, never want to be entirely subordinate to the power of the New Order. As a form of opposition to Suharto, some of NU's forces withdrew from the PPP in 1984, and some of the Masyumi descent built political forces from the grassroots through the da'wah movement (Solahudin 2011).

The description, hard to conclude that Indonesian political culture in this period is built by democratic power relation both in the upper political structure as well as what people believe or hold on. The 
elite still preserves the power traditionally to absorb and make the power personalised. The people, commonly, place primordial identity as prominence in orienting their political attitude. However, it does not mean that Indonesian civil society cannot make resistance measurement toward the New Order authoritarianism. During the 1980s-1990s, the democratic resistance led by figures such as Abdurrahman Wahid and Amien Rais, and some of the activist groups, gave significance counterwork against Suharto. Interestingly, the emergence of activist resistance against the New Order regime was concomitant by the development of ICTs. The Internet entered Indonesia in 1995 and the government bought satellites to support the Internet in 1997 (Woodier, 2009). Based on the survey results of the Association of Indonesian Internet Service Providers (APJII), in 1998, there were about 500,000 users (The-marketeers.com 2014). With the use of the Internet, activist groups could organise their movements without being able to be censored by the government. Various information was disseminated in a short time to multiple NGOs at home and abroad. They were equipped to roll out a real massive movement at a time when the economic crisis in 1997 hit the country and finally able to overthrow the Suharto regime (Hill \& Sen 2005).

\section{Political culture in the post-Suharto period: Direct election and mass media}

After the fall of the New Order regime in 1998, political democratisation increased. The new political reform emanated by allowing new political party establishments, a fairer election, and the legislative body rearrangements. In addition, the new government also enacted the Law No. 40/1999, which guarantee the freedom of the press, which followed by the endowment of mass media corporations. However, the central peculiarities of the New Order's political culture, such as primordialism and patronage continued, which the power fell mostly upon elites formerly beneath Suharto's auspices (Robison \& Hadiz 2004). At the government level, Indonesian bureaucrats still regard themselves as elites and tend to act as masters rather than public servants. Perhaps they realise they function as the remains of the aristocracy, the governing class that has enjoyed privilege since the colonial era. The strong character of nobility among bureaucrats is also influenced by weaknesses in the private sector and civil society, who did not control the government in the New Order (King 2000).

Although the open and fair elections had encouraged of broad political participation since the 1999 election, primordial tendencies remained salient. It is obstructing a meritocratic political system and highlighting traditional political figures (Singh 2003). Fair and open elections did not necessarily produce a rational or progressive political system. Corruption continued, and elite circles formed political dynasties that exercised power in their interest. In political institutions, patrimonial politics and patron-client relationships predominantly favour personal interests over public ones. The importance of charisma and loyalty to leaders resulted in a political competition dominated by mass mobilisation and the distribution of spoils among elites (Choi 2009). For example, the relationship between Megawati and her follower, which resembles traditional concepts of power relations, impacts the nature of her political parties, political constellations, and socioeconomic conditions (Ziv 2001). On the other hand, primordial bonds promoted voter behaviours reflecting ethnic, socio-cultural (aliran), and religious boundaries. There is a clear division between Islam and the secular nationalists, who put forth two influential figures who became leaders, Abdurrahman Wahid and Megawati. Each was involved in the practice of power via patrimony and political patronage. However, to create political stabilisation, they formed cabinets whose members were appointed not as patrimonial rewards, but instead to represent certain groups, ideologies, and powers (King 2000).

The dominance of primordial figures challenged after Indonesia enacted a direct election system accompanied by mass media popular preferences. In 2002, the People's Consultative Assembly (MPR) approved a system for the direct election of the country's 2004 president and vice president. In June 2005, the government enacted direct elections at the regional level to fit the decentralisation system. Since the imposition of direct elections, political parties have weakened at the local level, and struggles for power among local elites have increased. However, a direct election system, which aims to prevent political transactions between legislators and voters through vote-buying, has also transformed the financial practices of political parties (Choi 2009). Direct elections encouraged parties to make and act upon pragmatic decisions. Party coalitions in local elections were formed based on winning goal than the ideology or platform of the party (Ufen 2006). 
Direct elections made television a vital tool in influencing public opinion. Voters who formerly relied on traditional figures diverted attention to alternative candidates portrayed positively on television. A majority of votes determines a leader's legitimacy, and television has become a significant medium in garnering massive voter support. Television used as a source of information that informed the choices of $83 \%$ of voters, and about $30 \%$ of campaign funds spent on political television advertising (Ufen 2008). In this era, once lesser-known Susilo Bambang Yudhoyono (SBY) quickly gained momentum as a popular figure through his television appearances (Ufen 2006). The virtues of mass media mean a voter's decision is no longer determined by aliran. According to the results of Liddle \& Mujani's (2005) survey of the 2004 elections, SBY won the presidency with support from $82 \%$ of Partai Golkar voters, $78 \%$ of PPP voters, and even $29 \%$ of PDI-P voters. Mass media contributed to the prominence of psychological factors in determining political behaviour. However, television does not entirely replace traditional election strategies. Every candidate used mass mobilisation requiring the deployment of mass brokers who oversaw patronage patterns (Aspinall 2005).

However, the emergence of new media in electoral competition opened up significant potential for democratisation. Mass media, especially television, radio, and newspapers, increasingly played a role in government oversight (Freedman 2007). Because of these media, communities possessed broader information on political dynamics and could more substantively participate in such discourse. Theoretically, mass media is believed to have influenced the shift from patrimonialism to rationality. First, political parties who underperform are punished with less support in subsequent elections, regardless of socio-cultural basis. In the 2004 elections, PDIP votes fell sharply, even in their base of support in Central Java. Second, SBY's victory illustrated expertise in utilising mass media to garner support despite socio-cultural boundaries. However, cultural and religious identities not uprooted from electoral practices. Indeed, SBY's achievement backed by expert support from religious groups such as NU and Muhammadiyah's base. The religious identity influence on voter behaviour remained in general election 2004, where Islamic parties' voters were gain up to 38.35 per cent, slightly higher than in 1999, which they got 37.9 (Aspinall 2005).

\section{Indonesian democracy in the new digital age}

The robust popularity SBY built through mass media was unmatched in the 2009 elections. His reputation outpaced other candidates, and he easily won the election (Ahmad \& Herdiansah 2013). Nonetheless, despite his new media expertise, SBY continued to exercise patronage-based power for followers with strong political ambition. His party, the Partai Demokrat (PD) was known for building patronage-based clientele networks to address personal interests. Within the party, SBY's wife, children, and in-laws awarded extensive power, and party elites depended heavily on patronage and state power. After the 2009 elections, some of the PD's core cadres exposed by the Corruption Eradication Commission or Komisi Pemberantasan Korupsi (KPK). This corruption proved quite influential in the party's sharp 2014 decline (Hamayotsu 2015).

In his second administration (2009-2014), SBY no longer continued his presidential candidacy as the constitution limits only two terms of office. However, the media sought out new politicians to boost news ratings. Joko Widodo, better known as Jokowi, was a figure that came to the attention because of the uniqueness of the low-profile leadership style and representing a new hope for a clean leader. He initially ran for mayoral election of Solo, the small town in Central Java, in 2005. In 2010 , he won the second term of office with about $90 \%$ of the vote. His popular and preferred factfinding method, blusukan, made him a media darling. Jokowi suddenly became a top story within the nation's mass media (Taspell 2015). His successes as mayor of Solo were considered him as a strong candidate to govern the state's capital, Jakarta. In the 2012 Jakarta governor election, PDIP and Gerindra Party agreed to carry Jokowi alongside Basuki Tjahaja Purnama (Ahok). In the final round, Jokowi-Ahok dominated all mass media news except radio.

Moreover, new digital media were beginning to impact elections significantly. Jokowi is excellent performance in the 2012 Jakarta gubernatorial race was, in part, the result of the sympathy he won on social media, which paralleled with support from the youth (Mietzner 2014). At the time, Internet 
penetration in Indonesia had been measured at about $24.23 \%$, equal to 63 million citizens. Facebook reported 42.5 million users in the country. Twitter had as many as 19.5 million users, and about 3.5 million users frequented blogs (Utomo 2013). PoliticaWave research results showed that JokowiAhok dominated $54.9 \%$ of the overall conversation on Facebook, Twitter, blogs and online forums, online news, and YouTube. The social media management of Jokowi's team successfully translated to support from the country's youth and educated citizens. Jokowi is gubernatorial victory and the national media widely covered the first 100 days in office. Audiences eagerly awaited news about Jokowi, and he continued to enjoy substantial news coverage (Hamid 2014, Taspell 2015).

With the proliferation of new digital media, the democratisation of information and knowledge has inspired increasingly intense political involvement. The production and consumption of social media act as mechanisms for the massive distribution of content. It allowed Jokowi to dominate online media and, in turn, attract conventional media attention. For example, in June 2012 Jokowi produced and broadcasted a local youth music song that conveyed a clean government and anti-corruption message on YouTube. In just a few weeks, this video had attracted 2.5 million hits. Jokowi's online traffic won the attention of the mass media (Taspell 2015). The leading group of Jokowi calibre troops was Jokowi Ahok Social Media Volunteer (Jasmev), who organised around 90,000 online volunteers to overwhelm virtual discussions and elevate Jokowi as the dominant candidate. They were not only active in the social media but also move in the offline realm to preserve the support up to the election (Utomo 2013). After his electoral successes, Jokowi-Ahok continued to employ effective social media strategies to maintain popular support. His office pleased the public by displaying government activities and information on social media such as YouTube. Jokowi is social media strategy also allowed him to bypass the stranglehold of oligarchs and media owners. He mobilised online media activists among ordinary people to foster youth participation in the political arena. His victory is considered a breakthrough in politics, and Jokowi's success has cemented him as a national media star both on television and online (Taspell 2015).

The democratisation effect of social media also accompanies the emergence of Jokowi as a popular leader. It can be seen from the tendency of melting ethnic boundaries in the voting behaviour of the Jakarta 2012 gubernatorial election. Based on survey results presented at the time by the Saiful Mujani Research Center (SMRC), only $0.5 \%$ of voters voted for Jokowi based on religious similarities, and only $4.9 \%$ supported him because of ethnic similarities (Hamid 2014). This event indicates the potential of the Internet and social media to pull political preferences from primordialism. Jokowi is prominence within social media, and mass media continued ahead of the 2014 presidential election. His national popularity made him a strong candidate in the 2014 presidential election. Throughout 2013 and 2014, he consistently ranked first in the national poll of presidential candidates. An April 2014 Tempo report revealed that of about 8.2 million online social media conversations related to the presidential election, 6.9 million discussed Jokowi, while 1.3 million centred on other candidates (Taspell 2015).

In the time since Jokowi-Jusuf Kalla won the 2014 presidential election, the Internet and social media have become a broader arena for political debate. However, a strong trend with negative political debate has emerged, which social media has become a means through which opposing sides curse each other due to their contradicting views and tastes for political issues. Political friction within social media mainly arises between government supporters and those critical to the government regime and trigger awareness of the position of social identity. One such damaging hoax against the government declared that the Indonesia Communist Party (PKI) sympathisers had infiltrated the government. A PoliticaWave study stated that this hoaxed material dominated social media conversation from August to December 2017. Survey data also showed that content linking the government with the PKI circulated as much as over 200 thousand contents. Other governmentrelated news stories that used to attack the Jokowi's government are the content that stated Jokowi as anti-Islamic and the government that neglectful the Chinese labour invasion (Cnnindonesia. com February 10th, 2018). Attacks against Jokowi mainly come from Islamist websites, such as VOA-Islam.com, Arrahmah.com, and PKSPiyungan.com, which is full of harmful content to the government and Jokowi's personal life. Just the same from the camp Jokowi, they attack political 
opponents, especially Prabowo through the website Seword.com and GerilyaPolitik.com. They depicted Prabowo as a supporter of the Islamist hard-liners that threatening the state's unity (Kwok 2018). Jokowi's volunteers also slandered Prabowo that he would let Indonesia become a home ground for the radicals and fundamentalists if he won the 2019 presidential election (Cnnindonesia. com February 26th 2019). The strengthening of such identity issues indicates the political discourse on the Internet and social media leads to racist sentiment.

A political contest involving social identity, primarily ethnic and religious sentiments, permeates up to local elections, especially in the 2017 Jakarta gubernatorial race, where almost all Islamic party's voters vote for Anis-Sandi (Indikator 2017). In contrast to the 2012 Jakarta gubernatorial race, social media use in the 2017 race appears to have strengthened ethnic and religious barriers and steeped virtual debates in primordial nuance. The significant momentum corroborates this phenomenon was the 2017 Jakarta gubernatorial event, which was accompanied by mass protests demanding the imprisonment of Ahok for blasphemy against Islam. Beginning with Ahok's reckless statement on the Quran, which went viral on YouTube in September 2016, the calls for movement quickly spread to other social media spaces. Mass mobilisation and protests against Ahok succeeded in reducing his electability, even though he had initially dominated polls months before the race. In the end, Anis-Sandi previously considered as the weakest candidacy, won the election (Herdiansah, Putri, Ashari, \& Maduratmi 2017). The rise of content containing ethnic and religious sentiments colours debate within virtual spaces, and it is parallel with the voting behaviour at the election day. Based on a Political Indicator survey, there support against Ahok-Djarot and Anis-Sandi was firmly based on ethnicity and religion. The most significant ethnic groups who selected Ahok-Djarot were Chinese $(100 \%)$ and Batak (94\%), which are predominantly non-Muslim. Those ethnic groups who voted most often for Anis-Sandi were Betawi (75\%) and Sundanese (75\%), which are mostly Muslim. Although the survey also designated that satisfaction with Ahok leadership was consistently high, most of the voters did not choose Ahok-Djarot for religious sentiments (Ubaid \& Subandi 2018).

\section{Conclusion}

From the discussion above we get the picture that the dynamics of political culture have a strong correlation with the development of information technology and communication media. The characteristics of the political culture in the era of digital media do not yet exist, cultural scheme and traditions strongly dominated the power. In conditions where cultural values exalt harmony and stability, a pattern of political culture emphasising the centralisation of power resting on loyalty, patronage, and primordialism. The emergence of new media, the Internet, at the end of Suharto's rule had favoured the opposition camp which not only toppled the ruling regime but also encouraged the emergence of information liberalisation which in turn weakened the hegemonic political tendencies. In the post-Suharto, one can see how advanced media play an essential role in outweighing the power of primordialism in elections. In 2004, SBY's emergence driven by his capacity to use television media in his favour to defeat the charismatic Megawati. In 2012, with the power of social media, Jokowi emerged as the people's leader challenging a healthy military-style, Prabowo. However, in public discourse, extensive Internet and social media use has nurtured primordial sentiments. The 2017 Jakarta gubernatorial stirred intense political debate that has permeated to the frictions in the social sphere. As a result, discourse is often associated with ethnic and religious representation, and divisive content is on the rise.

The proliferation of new digital media usage in the political contest drive democratisation regarding a massified information dissemination and raising the ordinary people to be involved in the political process. However, at the same time, the process sparked awareness of identity positions, primarily ethnic and religion, which makes the online political discourse tinged with the racist sentiment. Although social media is supporting the democratisation of information, knowledge, and political discourses, subsequent developments have proven counterproductive to these ideals. Social media has become an unhealthy battleground for unsettled groups. The conflict between opposing political groups no longer seems rational and is plagued by identity sensitivity. This tendency will likely 
prove challenging to suspend. The Internet and social media's power to improve democratisation has become questionable. Finally, this article considers whether social media has paradoxically impacted Indonesian democracy. Long-standing and deep-rooted traits of political culture such as primordialism persist, even as the Internet and social media have expanded societal views. Furthermore, this study recommends additional in-depth empirical research into how friction on social media triggers real social cleavages and shapes political competition.

\section{References}

Ahmad NSY \& Herdiansah AG (2013) Ambiguity in Indonesian cartelized democracy: An analysis on the political communication. African and Asian Studies 12 (3):245-265.

Anderson B (1990) Imagined Communities. New York: Verso.

Anderson B (2006) Language and Power: Exploring Political Culture in Indonesia. United Kingdom: Equinox Pubslihing.

Aspinall E (2005) Elections and the normalization of politics in Indonesia. South East Asia Research 13 (2):117-156. DOI: 10.5367/0000000054604515.

Carnegie PJ (2008) Democratization and in post-Soeharto decentralization Indonesia: Understanding transition dynamics. Pacific Affairs 81 (4):515-525.

Choi N (2009) Democracy and patrimonial politics in local Indonesia. Indonesia 88 (88):131-164.

Cnnindonesia.com (2018, February $10^{\text {th }}$ ) Politica Wave Sebut Hoax Kebangkitan PKI Dominan di Medsos. https://www.cnnindonesia.com/nasional/20180209194859-32-275187/politica-wa ve-sebut-hoax-kebangkitan-pki-dominan-di-medsos.

Crouch H (2007) The army and politics in Indonesia. United Kingdom: Equinox Pubslihing.

Dalton RJ \& Welzel C (2014) Political culture and value change. In: RJ Dalton \& C Welzel (eds). The Civic Culture Transformed: From Allegiant to Assertive Citizens. New York: Cambridge University Press.

Diamond L (2012) Introduction. In: L Diamond \& MF Plattner (eds). Liberation Technology: Social Media and the Struggle for Democracy. Baltimore: The Jhons Hopkins University Press.

Eklof S (2004) Power and Political Culture in Suharto's Indonesia: The Indonesian Democratic Party (PDI) and the Decline of the New Order (1986-98). London: Routledge.

Freedman AL (2007) Consolidation or withering away of democracy? political changes in Thailand and Indonesia. Asian Affairs: An American Review 33 (March 2014):195-216. DOI: 10.3200/ aafs.33.4.195-216.

Geertz C (1976) The Religion of Java. Chicago: University of Chicago Press.

Hamayotsu K (2015) Indonesia in 2014: The year of electing the "People's President". Asian Survey 55 (1):174-183.

Hamid A (2014) Jokowi's populism in the 2012 Jakarta gubernatorial election. Journal of Current Southeast Asian Affairs 33 (1):85-109. DOI:10.1177/186810341403300105.

Herdiansah AG, Putri DA, Ashari L, \& Maduratmi R (2017) The Islam defence action: A challenge of Islamic movement to democratic transition in the post 2014 Indonesia. Jurnal Wacana 20 (2):57-67.

Heryanto A (2008) Pop culture and Competing Identities. In: A Heryanto (ed). Popular Culture in Indonesia: Fluid Identities in Post-Authoritarian Politics. New York: Routledge.

Hill DT \& Sen K (2005) The Internet in Indoneisa's New Democracy. London \& New York: Routledge.

Huntington SP (1991) Democracy's third wave. Journal of Democracy 2 (2):12-34.

Inglehart R (1990) Culture Shift in Advanced Industrial Society. New Jersey: Princeton University Press.

King DY (2000) Corruption in Indonesia: A curable cancer? Journal of International Affairs 53 (2):603-624. 
King DY (2003) Half-hearted Reform: Electoral Institutions and the Struggle for Democracy in Indonesia. Development. Portsmouth: Greenwood Publishing Group.

Kwok Y (2018) Indonesia. In: M Kajimoto \& S Stanley (eds). Information Disorder in Asia: Overview of misinformation ecosystem in India, Indonesia, Japan, the Philippines, Singapore, South Korea, and Taiwan. Hongkong: Journalism and Media Studies Center at the University of Hongkong.

Lange M (2013) Comparative-Historical Methods. Los Angeles, London, Delhi, Singapore, Washington DC: SAGE Publications Ltd.

Leadbeater C (2010) We-Think: Mass Innovation, Not Mass Production. London: Profile Books.

Liddle RW \& Mujani S (2005) Indonesia in 2004: The rise of Susilo Bambang Yudhoyono. Asian Survey 45 (1):119-126.

Lin CA (2007) Communication Technology and Social Change. In: CA Lin \& DJ Atkin (eds). Communication Technology and Social Change: Theory and Implication. New York: Routledge.

Loader BD \& Mercea D (2012) Networking Democracy? Social Media Innovations in Participatory Politics. In: Mercia D \& Loader BD (eds). Social Media and Democracy: Innovations in Participatory Politics. New York: Routledge.

Mietzner M (2014) Indonesia's 2014 elections: How Jokowi won and democracy survived. Journal of Democracy 25 (4):111-125.

Nordholt HS (2015) From contest state to patronage democracy the longue durée of clientelism in Indonesia. In: D Henley \& HS Nordholt (eds). Environment, Trade and Society in Southeast Asia. London: Brill.

Patel F, Sooknanan P, Rampersad G, \& Mundkur A (2012) Information Technology, Development, and Social Change. New York: Routledge.

Ragin CC (2014) Comparative Method: Moving Beyond Qualitative and Quantitative Strategies. California: University of California Press.

Reeve D (2013) Golkar Sejarah Yang Hilang: Akar Pemikiran \& Dinamika. Depok: Komunitas Bambu.

Schwartz LH, Libicki MC, Taylor JE, Martini J, \& Baxter C (2013) The Internet and Political Precess in Different Regimes. In Internet Freedom and Political Space. California: RAND Corporation.

Sen K \& Hill DT (2007) Media, Culture, and Politics in Indonesia. Jakarta, Kuala Lumpur: Equinox Pubslihing.

Singh B (2003) The 2004 presidential elections in Indonesia: Much ado about nothing? Contemporary Southeast Asia 25 (3):431-448.

Skoric MM, Park YJ, \& Jiang Y (2014) Cultural values and digital network as predictor of sustainable democratic development. In: J Servaes (ed). Technological Determinism and Social Change: Communication in the Tech-Mad World. Lanham, Boulder, New York, London: Lexington Books.

Solahudin (2011) NII Sampai JI: Salafy Jihadisme di Indonesia. Depok: Komunitas Bambu.

Sparks C (2014) Technological innovation and social change. In: J Servaes (ed). Technological Determinism and Social Change: Communication in the Tech-Mad World. Lanham, Boulder, New York, London: Lexington Books.

Stacey E (2015) The pamphlet meets API: An overview of social movements in the age of social media. In: V Kumar \& J Svensson (eds). Promoting Social Change dan Democracy Through Information Technology. USA: IGI Global.

Suryadinata L (1997) Democratization and political succession in Suharto's Indonesia. Asian Survey 37 (3):269-280. 
Sustein CR (2018) \#Republic: Divided Democracy in the Age of Social Media. New Jersey: Princeton University Press.

Taspell R (2015) Indonesia's media oligarchy and the "Jokowi Phenomenon." Indonesia 99 (April 2015): 29-50. DOI:10.1353/ind.2015.0004.

The-marketeers.com (2014) MarkPlus Insight: Pengguna Internet Indonesia 74 juta di Tahun. [Accessed 20 June 2018]. http://www.the-marketeers.com/archives/Indonesia Internet Users.html.

Ubaid AHH \& Subandi H (2018) Political polarization based on religious identities: Empirical evidence from the 2017 Jakarta gubernatorial. Jurnal Studi Pemerintahan 8 (4):411-441.

Ufen A (2006) Political Parties in Post-Suharto Indonesia: Between Politik Aliran and 'Philippinisation'. GIGA: Hamburg.

Ufen A (2008) From "aliran" to dealignment: Political parties in post-Suharto Indonesia. Southeast Asian Affairs 16 (1):5-41. DOI:10.5367/000000008784108149.

Utomo WP (2013) Menimbang media sosial dalam marketing politik di Indonesia: Belajar dari Jokowi-Ahok di pilkada DKI Jakarta 2012. Jurnal Ilmu Sosial dan Ilmu Politik 17 (1):67-84.

Welch S (1993) The Concept of Political Culture. London: The Macmillan Press Ltd.

Welch S (2013) The Politics of Political Culture. Oxford: Oxford University Press.

Wiarda HJ (2014) Political Culture, Political Science, and Identity Politics: An Uneasy Alliance. Ashgate. London \& New York: Routledge.

Woodier J (2009) The Media and Political Change in Southeast Asia: Karaoke Culture and the Evolution of Personality Politics. UK, USA: Edward Elgar Publishing.

Ziv D (2001) Populist perceptions and perceptions of populism in Indonesia. The case of Megawati Soekarnoputri. South East Asia Research 9 (1):73-88. DOI:10.5367/000000001101297324. 